\section{UK panels need more clout}

\section{London}

RESEARCH ethics committees (REC) in Britain do not have the muscle to carry out their job of overseeing clinical experiments on humans, according to a report issued last week* by the independent King's Fund Institute. But none of the several ways to make them stronger - including new legislation and clearer rules from their authorizing bodies - are likely to occur.

The ethics committees were set up somewhat haphazardly in the 1960 s at the prompting of the Royal College of Physicians. There are about 270 committees, most answering to the district health authorities under which they operate. In addition to reviewing research on National Health Service patients, the ethics committees also consider volunteer studies at universities and medical schools. A large proportion of the work involves therapeutic studies sponsored by the pharmaceutical industry, but the scope of activity goes from basic medical research to nursing studies.

Despite a willingness on the part of the medical research community and the pharmaceutical industry to accept some sort of legislative framework, it is unlikely that the UK government will go further than the general guidelines issued by the Department of Health last August. With the exception of the 1990 law that allows research on human embryos no older than 14 days, Britain has a distinct disinclination to legislate on medical ethics.

According to the author of the report, Julia Neuberger, a concerted effort by the

\title{
Beyond apartheid - on the cheap
}

\section{Cape Town}

IN the wake of the dismantling of apartheid, South African scientists are busy renewing their ties with the rest of the world. They no longer seem to have problems obtaining visas for overseas visits, nor are they being excluded from international conferences. But reintegrating the country into the global scientific community seems likely to be slowed by the universal difficulty of obtaining funds for international initiatives.

In a recent example of shifting attitudes towards the formerly outcast nation, the American Physical Society (APS) has issued a statement encouraging interaction between individual scientists in the United States and South Africa. Referring to the financial and social stresses that have jeopardized the training of African scientists, the statement says that "the isolation of South African teachers and faculty from external colleagues makes it even more difficult to train and maintain a core of qualified scientists". But APS warns that, although the political climate at last favours closer ties to South Africa, available resources are likely to be applied to more pressing needs.

In the field of nuclear power, relations have improved rapidly since last summer, when South Africa agreed to abide by the Nuclear Non-Proliferation Treaty. The South African Atomic Energy Corporation (AEC) immediately invited cooperation from the eight member states of Afra, the African section of the International Atomic Energy Agency, under the aegis of the agency's technical assistance programme. Kenya and Ghana both agreed to visit South Africa.

The chief science secretary for the Kenyan National Council for Science and
Technology, Ammon Oyango, will nominate South Africa to become a member of Afra at an association meeting this week. South Africa and Kenya are due to draft a bilateral agreement on nuclear cooperation. According to Waldo Stumpf, chief executive of the AEC, such an agreement would allow South Africa to export radioactive isotopes for medical and industrial purposes to Kenya, and to train Kenyans in isotope production.

Stumpf says that South Africa's adoption of the terms of the non-proliferation treaty has generated a stream of visitors from leading nuclear powers. In addition, it has enabled the corporation to export uranium hexafluoride and enriched uranium for the first time.

South Africa remains excluded from two other international scientific organizations, the United Nations' Economic, Scientific and Cultural Organization (UNESCO) and its Environmental Programme. But it appears doubtful that the country would consider payment of UNESCO dues worthwhile and affordable at a time when science funding is shrinking (see Nature 356, 278; 1992).

Scientific cooperation must also conform to political developments. Ania Grobicki, national convener of the science and technology group for the African National Congress (ANC), says that it is premature for other governments to seek bilateral agreements with South Africa before a multiracial government is established there. Although the ANC encourages cooperation between individual scientists in South Africa and elsewhere, she says that "we are opposed to people seeking to sign agreements at a national level which it would be difficult for a future government to review". Michael Cherry district health associations and other authorizing bodies could go a long way to solving some of the inconsistencies in the way committees are comprised and the way they operate. Britain lags behind other European countries, she says, citing legislation passed by France in 1990 that established consultative committees - similar in role to the RECs - in each region of France, with medical inspectors from the ministry of health overseeing the whole system. In the Irish Republic, pharmaceutical trials are policed by a team of inspectors from the National Drugs Advisory Board in Dublin, a system set up following the death of a healthy volunteer who was involved in more than one trial.

In addition, guidelines issued by the European Commission in 1990 on clinical trials are likely to be turned into a directive later this year. This already has the support of several European states, including Britain, but its effect is expected to be limited to preventing fraud.

The report found that some RECs were unsure whether to review the value of the research as well as the ethical issues it raised. Another worry was that clinical research is increasingly driven by the needs of the pharmaceutical industry, in particular 'me-too' drugs that are designed to challenge successful products.

The pharmaceutical industry does not think that the committees are the proper forum for discussing the value of proposed research. "That has nothing to do with ethics", commented Frank Wells, medical director of the Association of the British Pharmaceutical Industry. "Anything of likely therapeutic value should be tested."

But David Evered, second secretary to the Medical Research Council, says that the committees have an obligation to examine the issue of quality. "Any research which is unsound is unethical", he says. "There is a plurality of funding sources, some of which are softer than others, that may be used to support activities which have not been subject to peer review."

Evered agrees with the report's suggestion that RECs should have access to external expertise to assess the quality of research if their members are so lacking.

Ian Mundell

* Ethics and Health Care, King's Fund Institute, 1992; send $£ 7.95$ to Bournemouth English BookCentre, 9 Albion Close, Parkstone, Poole, Dorset, BH12 3LL.

\section{Corrections}

A recent News item (Nature 356, 549; 16 April 1992) incorrectly stated that there are $20 \mathrm{PhDs}$ in the genome centre at the Whitehead Institute of Biomedical Research in Cambridge, Massachusetts. The correct number is about 20 staff members in total, including students and technicians.

A recent News and Views (Nature 356, 473; 9 April 1992) mistakenly reported that there are 25,000 cases of tuberculosis in New York City. In fact, that number applies to the United States as a whole. The figure for New York City is 3,500 TB cases. 